\title{
Adsorption and electrokinetic potentials at solid/aqueous solution interfaces characterized by mutually stimulated adsorption of cations and anions
}

Citation for published version (APA):

Diemen, van, A. J. G., \& Stein, H. N. (1978). Adsorption and electrokinetic potentials at solid/aqueous solution interfaces characterized by mutually stimulated adsorption of cations and anions. Journal of Colloid and Interface Science, 67(2), 213-218. https://doi.org/10.1016/0021-9797(78)90004-8

DOI:

10.1016/0021-9797(78)90004-8

Document status and date:

Published: 01/01/1978

Document Version:

Publisher's PDF, also known as Version of Record (includes final page, issue and volume numbers)

\section{Please check the document version of this publication:}

- A submitted manuscript is the version of the article upon submission and before peer-review. There can be important differences between the submitted version and the official published version of record. People interested in the research are advised to contact the author for the final version of the publication, or visit the DOI to the publisher's website.

- The final author version and the galley proof are versions of the publication after peer review.

- The final published version features the final layout of the paper including the volume, issue and page numbers.

Link to publication

\footnotetext{
General rights

- You may freely distribute the URL identifying the publication in the public portal. follow below link for the End User Agreement:

www.tue.nl/taverne

\section{Take down policy}

If you believe that this document breaches copyright please contact us at:

openaccess@tue.nl

providing details and we will investigate your claim.
}

Copyright and moral rights for the publications made accessible in the public portal are retained by the authors and/or other copyright owners and it is a condition of accessing publications that users recognise and abide by the legal requirements associated with these rights.

- Users may download and print one copy of any publication from the public portal for the purpose of private study or research.

- You may not further distribute the material or use it for any profit-making activity or commercial gain

If the publication is distributed under the terms of Article $25 \mathrm{fa}$ of the Dutch Copyright Act, indicated by the "Taverne" license above, please 


\title{
Adsorption and Electrokinetic Potentials at Solid/Aqueous Solution Interfaces Characterized by Mutually Stimulated Adsorption of Cations and Anions
}

\author{
A. J. G. VAN DIEMEN AND H. N. STEIN \\ Laboratory of General Chemistry, Eindhoven University of Technology, Eindhoven, The Netherlands
}

Received December 22, 1977; accepted May 10, 1978

\begin{abstract}
For interfaces of some $\mathrm{Ca}$ silicates with aqueous solutions, the change of the potential in the chemisorption plane with $\mathrm{Ca}^{2+}$ activity in the surrounding liquid is calculated from adsorption data. The potential, averaged over the $\mathrm{Ca}^{2+}$ sites, increases less with increasing $\mathrm{Ca}^{2+}$ activity than the $\zeta$ potential and the potential averaged over the whole chemisorption plane. In some cases, distances between the electrokinetic slipping and chemisorption planes may be calculated (1-2.5 nm); these distances may be too low because any surface disorder will increase these values, but they may be overestimated because any lowering of the relative dielectric constant near the surface will lead to lower values.
\end{abstract}

\section{INTRODUCTION}

One of the problems in colloid chemistry, about which there is at present no unanimity of opinion, is the question how far a "stagnant" layer of water near a solid/aqueous electrolyte solution interface extends into the liquid. Whereas some authors [see, e.g., Ref. (1)] present arguments for the existence of a layer of "vicinal" water of several hundred molecular diameters, others (2) arrive at an identity of the $\zeta$ potential and $\psi_{\delta}$, the potential at the outer Helmholtz plane. This uncertainty implies an inaccuracy in the interpretation of electrokinetic data (3).

In a previous paper (4), it was shown that on $\alpha-\mathrm{CaSiO}_{3} /$ aqueous electrolyte solution interfaces, simultaneous adsorption of $\mathrm{Ca}^{2+}$ and $\mathrm{OH}^{-}$occurs in a nearly stoichiometric ratio, which, however, should not be referred to as "surface precipitation" of $\mathrm{Ca}(\mathrm{OH})_{2}(5)$, but rather as mutually stimulated adsorption of cat- and anions. A comparison of adsorption and electrokinetic potentials, which might answer the question whether $\zeta=\psi_{\delta}$ for the interfaces con- cerned, should then comprise an average potential in the plane of chemisorbed ions (henceforth referred to as the "chemisorption plane').

We measured therefore electrokinetics and de- or adsorption isotherms for the ions involved in surface charge generation at some silicate/aqueous electrolyte solution interfaces. As solids, $\beta-\mathrm{CaSiO}_{3}$ (wollastonite) and $\mathrm{Ca}_{6} \mathrm{Si}_{6} \mathrm{O}_{17}(\mathrm{OH})_{2}$ (xonotlite) were chosen because they have closely related structures (6) and equal $\mathrm{Ca} / \mathrm{Si}$ ratios, which permits certain conclusions on the effects of surface layer structure on adsorption (see the following). The liquid medium consisted of aqueous $\mathrm{NaOH}$ solutions of a constant $\mathrm{OH}^{-}$concentration and varying $\mathrm{CaCl}_{2}$ concentrations. Details of the experimental procedures, solid material preparations, and results are described elsewhere (7). The reversibility of the adsorption data was checked by replacing part of the supernatant after adsorption equilibrium establishment with a $\mathrm{CaCl}_{2}$-free $\mathrm{NaOH}$ solution and shaking; the surface charges calculated from the analyses of the aqueous solution after such a desorption stage were in agree- 
ment with data obtained on adsorption starting from a lower $\mathrm{CaCl}_{2}$ concentration but ending at an equal $\mathrm{Ca}^{2+}$ concentration. Desorption equilibrium establishment, however, took more time ( $24 \mathrm{hr}$ ) than adsorption equilibrium establishment $(2.5 \mathrm{hr})$. From these results, we conclude that the adsorption isotherms can be described as (metastable) equilibria, at least for xonotlite. Formation of a surface layer consisting of, e.g., silicic acid is excluded by the fact that, even in $\mathrm{CaCl}_{2}$-free $\mathrm{NaOH}$ solutions, the amount of $\mathrm{Ca}^{2+}$ desorbed never exceeded that present in the unit cells at the surfaces of the solids.

Of both solids, samples of different $\mathrm{Na}$ contents were investigated $([\mathrm{Na}]=$ ca. 25 ppm for xonotlite I and II and wollastonite I and II; $[\mathrm{Na}]=\mathrm{ca} .500 \mathrm{ppm}$ for xonotlite III and wollastonite III). Effects of differences in $\mathrm{Na}$ content on the comparison between xonotlite and wollastonite samples can be eliminated by comparing xonotlite with wollastonite samples of equal $\mathrm{Na}$ content. Thus, wollastonite I was prepared by thermally decomposing xonotlite I, etc. (7).

Simultaneous adsorption of $\mathrm{Ca}^{2+}$ and $\mathrm{OH}^{-}$was found, leveling off at a surface charge $\sigma \approx 0.7 \mathrm{C} \cdot \mathrm{m}^{-2}$ at high $\left[\mathrm{CaCl}_{2}\right]$. This maximum surface charge agrees reasonably well with the surface charge calculated from the crystal structures (6) for ideal cleavage planes in the 100 and 001 directions (viz. $0.618 \mathrm{C} \cdot \mathrm{m}^{-2}$ ). The diffuse double-layer charge was taken account of in all cases by the usual formulas (8), but was found to be negligible.

In the present paper, the results will be employed to calculate distances between the electrokinetic slipping and chemisorption planes.

\section{THEORY}

The "chemisorption plane" is defined here as the locus of places where ions can become chemisorbed; this plane will not be mathematically flat, nor can the electrical potential in this plane be taken as a constant. However, the diversity of the electrical potential is taken into account as follows.

We assume that for all ionic species involved in surface charge generation $\left(\mathrm{Ca}^{2+}\right.$, $\mathrm{OH}^{-}$, silicate) there are different types of adsorption sites, $\mathrm{OH}^{-}$adsorption includes dissociation of surface $\equiv \mathrm{SiOH}$ groups. Desorption is described as negative adsorption. $\mathrm{A} \mathrm{Ca}^{2+}$ adsorption site of type $i$ is characterized by the sum of a standard chemical adsorption term and a local electrical potential term: $\mu_{i \mathrm{Ca}}{ }^{*}(\mathrm{ads})+2 F \phi_{i \mathrm{Ca}}$. Similarly, a $\mathrm{OH}^{-}$site is characterized by $\mu_{\mathrm{iOH}}{ }^{*}(\mathrm{ads})-F \phi_{i \mathrm{OH}}$ and a silicate site by $\mu_{\text {isil }}{ }^{*}(\mathrm{ads})-2 F \phi_{\text {isil }}$. The choice for the silicate ions is based on the consideration that hydrolytic splitting of the $\left[-\mathrm{SiO}_{3}{ }^{2-}-\right]_{\infty}$ chains in wollastonite and similar chains in xonotlite results in $\mathrm{H}_{2} \mathrm{SiO}_{4}{ }^{2-}$ ions leaving the solid.

The local potential, $\phi_{i}$, is defined as the potential which is operative at the site when an ion, to be adsorbed, approaches the site or when an adsorbed ion enters upon a desorption process, with the provision that the potential due to the ion to be ad- or desorbed is not included in $\phi_{i}$. Interaction with ions adsorbed on neighboring sites, however, is included in $\phi_{i}$, and other than electrostatic interaction with neighbor ions is neglected. Thus, the character of a site may change through an adjacent site becoming occupied.

The chemical potential of $\mathrm{Ca}^{2+}$ ions adsorbed on a site of type $i$ can then be expressed as $\mu_{i \mathrm{Ca}} *(\mathrm{ads})+2 F \phi_{i \mathrm{Ca}}+R T$ $x \ln \left[\theta_{i \mathrm{Ca}} /\left(1-\theta_{i \mathrm{Ca}}\right)\right]$, if $\theta_{i \mathrm{Ca}}=$ the fraction of sites of type $i$ which is occupied. The equality of electrochemical potential of the calcium ions throughout the system requires:

$$
\begin{aligned}
\ln \left[\theta_{i \mathrm{Ca}} /\left(1-\theta_{i \mathrm{Ca}}\right)\right] \\
\quad=\left[\mu_{\mathrm{Ca}} *(\mathrm{sol})-\mu_{i \mathrm{Ca}} *(\mathrm{ads})-2 F \phi_{i \mathrm{Ca}}\right] / R T \\
+\ln \gamma_{\mathrm{Ca}} m_{\mathrm{Ca}} . \quad[1]
\end{aligned}
$$

Here, $\gamma_{\mathrm{Ca}}$ is the activity coefficient of the calcium ions in the solution and $m_{\mathrm{Ca}}$ is their 
molality. After differentiation with respect to In $\gamma_{\mathrm{Ca}} m_{\mathrm{Ca}}$, rearrangement, and summation of $d \theta_{i \mathrm{Ca}} / d \ln \gamma_{\mathrm{Ca}} m_{\mathrm{Ca}}$ over all types of $\mathrm{Ca}^{2+}$ sites, we obtain (4)

$$
\begin{aligned}
& \frac{d X_{\mathrm{Ca}}}{d \ln \gamma_{\mathrm{Ca}} m_{\mathrm{Ca}}} \\
& =\int \frac{d \theta_{i \mathrm{Ca}}}{d \ln \gamma_{\mathrm{Ca}} m_{\mathrm{Ca}}} d N_{i \mathrm{Ca}} \\
& =\left[1-\frac{d}{d \ln \gamma_{\mathrm{Ca}} m_{\mathrm{Ca}}}\left(\frac{2 F \bar{\phi}_{\mathrm{Ca}}}{R T}\right)\right] \\
& \times \int \theta_{i \mathrm{Ca}}\left(1-\theta_{i \mathrm{Ca}}\right) d N_{i \mathrm{Ca}} \text {, }
\end{aligned}
$$

where $X_{\mathrm{Ca}}=$ the total amount of $\mathrm{Ca}^{2+}$ adsorbed $=\sum_{i} N_{i \mathrm{Ca}} \theta_{i \mathrm{Ca}}, N_{i \mathrm{Ca}}=$ the number of $\mathrm{Ca}^{2+}$ sites of type $i$, and

$$
\bar{\phi}_{\mathrm{Ca}}=\frac{\int \theta_{i \mathrm{Ca}}\left(1-\theta_{i \mathrm{Ca}}\right) \phi_{i \mathrm{Ca}} d N_{i \mathrm{Ca}}}{\int \theta_{i \mathrm{Ca}}\left(1-\theta_{i \mathrm{Ca}}\right) d N_{i \mathrm{Ca}}} .
$$

Similarly, for $\mathrm{OH}^{-}$and silicate ions:

$$
\begin{aligned}
& \frac{d X_{\mathrm{OH}}}{d \ln \gamma_{\mathrm{Ca}} m_{\mathrm{Ca}}}= {\left[\frac{d \ln \gamma_{\mathrm{OH}} m_{\mathrm{OH}}}{d \ln \gamma_{\mathrm{Ca}} m_{\mathrm{Ca}}}\right.} \\
&+\left.\frac{d}{d \ln \gamma_{\mathrm{Ca}} m_{\mathrm{Ca}}}\left(\frac{F \bar{\phi}_{\mathrm{OH}}}{R T}\right)\right] \\
& \times \int \theta_{i \mathrm{OH}}\left(1-\theta_{i \mathrm{OH}}\right) d N_{\mathrm{iOH}}, \\
& \frac{d X_{\mathrm{sil}}}{d \ln \gamma_{\mathrm{Ca}} m_{\mathrm{Ca}}}=\left[\frac{d \ln \gamma_{\mathrm{sil}} m_{\mathrm{sil}}}{d \ln \gamma_{\mathrm{Ca}} m_{\mathrm{Ca}}}\right. \\
&\left.+\frac{d}{d \ln \gamma_{\mathrm{Ca}} m_{\mathrm{Ca}}}\left(\frac{2 F \bar{\phi}_{\mathrm{sil}}}{R T}\right)\right] \\
& \times \int \theta_{i \mathrm{sil}}\left(1-\theta_{\text {isil }}\right) d N_{i \mathrm{sil}} .
\end{aligned}
$$

Average potentials such as those defined by Eq. [3] may differ from the true average potential:

$$
\bar{\phi}=\int \theta_{i} \phi_{i} d N_{i} / \int \theta_{i} d N_{i}
$$

However, if no systematic relation exists between $\phi_{i}$ and $\mu_{i}^{*}(\mathrm{ads})$, i.e., if sites of different $\mu_{i}{ }^{*}$ (ads) are distributed at random over the surface, no difference between the averages defined by Eqs. [3] and [6] is expected.

From the adsorption data, $X_{\mathrm{Ca}}, X_{\mathrm{OH}}$, and $X_{\text {sil }}$ are known as $f\left(m_{\mathrm{Ca}}\right) \cdot \gamma_{\mathrm{Ca}}$ was calculated by taking into account the formation of $\mathrm{Ca}(\mathrm{OH})^{+}$according to Hopkins and Wulff (9) and the activity coefficients of free ions according to Davies (10) using an iterative procedure. Then, from Eqs. [2], [4], and [5], $d \bar{\phi} / d \ln \gamma_{\mathrm{Ca}} m_{\mathrm{Ca}}$ can be calculated for the $\mathrm{Ca}^{2+}, \mathrm{OH}^{-}$, and silicate sites, if $\sum_{i} N_{i} \theta_{i}\left(1-\theta_{i}\right)$ is known for the three ionic species. For the $\mathrm{Ca}^{2+}$ ions, this can be calculated if the distribution of the sites as a function of $u=\left[\mu_{\mathrm{Ca}}{ }^{*}(\mathrm{sol})-\mu_{i \mathrm{Ca}}{ }^{*}(\mathrm{ads})\right.$ $\left.-2 F \phi_{i}\right] / R T$ is known; from Eq. [1], it follows that

$\theta_{i \mathrm{Ca}}=\gamma_{\mathrm{Ca}} m_{\mathrm{Ca}} \exp u /\left(1+\gamma_{\mathrm{Ca}} m_{\mathrm{Ca}} \exp u\right)$,

and then

$$
\begin{array}{r}
\int \theta_{i \mathrm{Ca}}\left(1-\theta_{i \mathrm{Ca}}\right) d N_{i \mathrm{Ca}}=\int_{-\infty}^{+\infty} \frac{d N_{i}}{d u} \\
\times \frac{\gamma_{\mathrm{Ca}} m_{\mathrm{Ca}} \exp u}{\left(1+\gamma_{\mathrm{Ca}} m_{\mathrm{Ca}} \exp u\right)^{2}} d u .
\end{array}
$$

Similar relations can be derived for the other ionic species. We assumed a Gauss distribution:

$\frac{d N_{i}}{d u}=\frac{N_{\mathrm{s}}}{w(2 \pi)^{1 / 2}} \exp \left[-(u-f)^{2} /\left(2 w^{2}\right)\right]$,

with $N_{\mathrm{s}}=$ the total number of sites of the ion concerned, taken such as to agree with $|\sigma|_{\max }=0.7 \mathrm{C} \cdot \mathrm{m}^{-2}$.

For $\gamma_{\mathrm{Ca}} m_{\mathrm{Ca}}=0.001 \mathrm{M}, f$ was calculated for different values of $w$ as follows: A particular value was given to $w$, and then $f$ was adjusted such as to make

$$
\begin{aligned}
\sum_{i} N_{i} \theta_{i}= & \int_{u=-\infty}^{+\infty} \frac{d N_{i}}{d u} \\
& \times \frac{\gamma_{\mathrm{Ca}} m_{\mathrm{Ca}} \exp u}{\left(1+\gamma_{\mathrm{Ca}} m_{\mathrm{Ca}} \exp u\right)} d u
\end{aligned}
$$




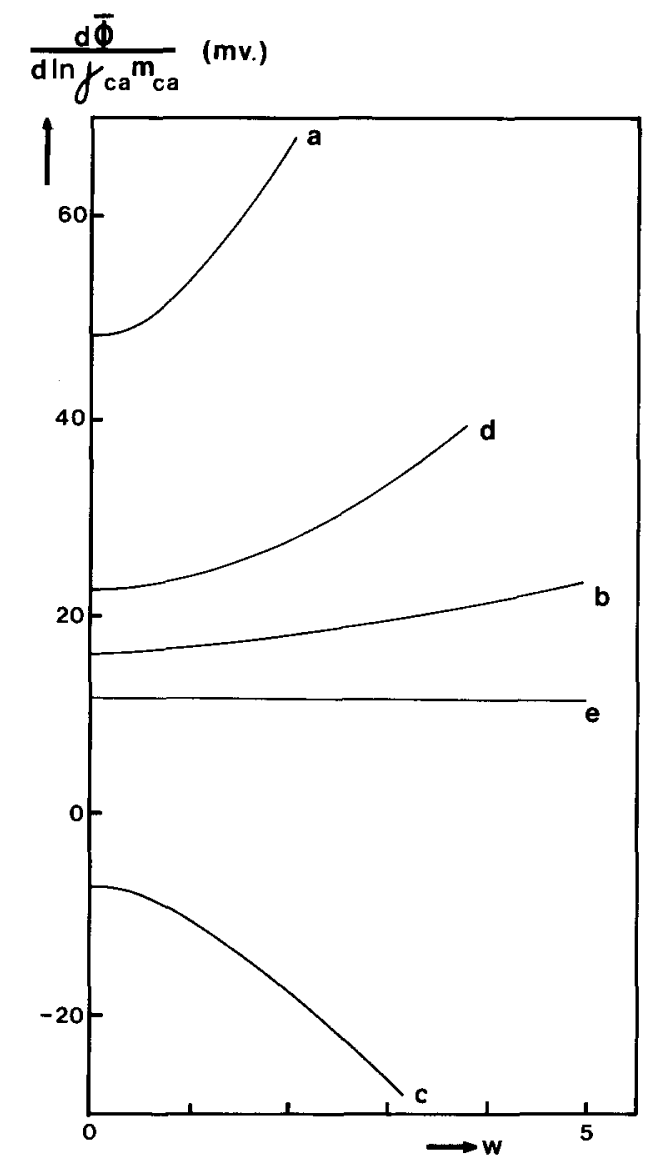

FiG. 1. $d \bar{\phi} / d \ln \gamma_{\mathrm{Ca}} m_{\mathrm{Ca}}$ as a function of $w$ (standard deviation) for xonotlite II $(0.01 M \mathrm{NaOH})$. (a) For $\mathrm{OH}^{-}$sites; (b) for silicate sites; (c) for $\mathrm{Ca}^{2+}$ sites; (d) averaged over the chemisorption plane; (e) $d \zeta / d \ln \gamma_{\mathrm{Ca}} m_{\mathrm{Ca}}$.

agree with the experimental value, $X_{\text {Ca }}$, observed at this $\mathrm{Ca}^{2+}$ activity; with the combination of $f$ and $w$ thus obtained, $\sum_{i} N_{i} \theta_{i}\left(1-\theta_{i}\right)$ was calculated using Eqs. [8] and [9]. Finally $d \bar{\phi} / d \ln \gamma_{\mathrm{Ca}} m_{\mathrm{Ca}}$ is obtained from Eq. [2], [4], or [5] for all species concerned, as a function of $w$.

\section{RESULTS AND DISCUSSION}

A typical result is shown in Fig. 1; some additional data are mentioned in Table $I$. Generally (with one exception, which is thought to be within the inaccuracy of the data), $d \bar{\phi} / d \ln \gamma_{\mathrm{Ca}} m_{\mathrm{Ca}}$ for the $\mathrm{Ca}^{2+}$ sites, for $w=0$ (i.e., absence of surface disorder), is found to be $\leqslant d \zeta / d \ln \gamma_{\mathrm{Ca}} m_{\mathrm{Ca}}$. This discrepancy increases with increasing $w$ (see Fig. 1). It may be argued that the model employed for the distribution of the sites as $f(u)$ is rather arbitrary. However, similar results were obtained with a different type of distribution:

$$
\begin{aligned}
& \frac{d N_{i}}{d u}=0 \text { for } u<u_{\mathrm{a}} \text { and } u_{\mathrm{b}}<u, \\
& \frac{d N_{i}}{d u}=\frac{N_{\mathrm{s}}}{u_{\mathrm{b}}-u_{\mathrm{a}}} \text { for } u_{\mathrm{a}}<u<u_{\mathrm{b}},
\end{aligned}
$$

with $u_{\mathrm{a}}$ and $u_{\mathrm{b}}=$ constants.

On the other hand, $d \bar{\phi} / d \ln \gamma_{\mathrm{Ca}} m_{\mathrm{Ca}}$ averaged over the chemisorption plane must be $\geqslant d \zeta / d \ln \gamma_{\mathrm{Ca}} m_{\mathrm{Ca}}$, since the opposite would imply that the electrokinetic slipping plane be situated closer to the solid/liquid phase boundary than the chemisorption plane, i.e., that water molecules be able to move with respect to the solid, between the chemisorbed ions. Thus, $d \bar{\phi} / d \ln \gamma_{\mathrm{Ca}} m_{\mathrm{Ca}}$ averaged over the chemisorption plane differs significantly from $d \bar{\phi} / d \ln \gamma_{\mathrm{Ca}} m_{\mathrm{Ca}}$ averaged over the $\mathrm{Ca}^{2+}$ sites only; in particular, $\left(d \bar{\phi} / d \ln \gamma_{\mathrm{Ca}} m_{\mathrm{Ca}}\right)_{\mathrm{Ca}}<\left(d \bar{\phi} / d \ln \gamma_{\mathrm{Ca}} m_{\mathrm{Ca}}\right)_{\text {overall }}$. This corroborates our previous findings about stimulated adsorption (4).

An overall averaged potential change in the chemisorption plane was calculated according to

$$
\begin{aligned}
& \left(\frac{d \bar{\phi}}{d \ln \gamma_{\mathrm{Ca}} m_{\mathrm{Ca}}}\right)_{\text {overall }} \\
& =\frac{1}{3}\left(\left(\frac{d \bar{\phi}}{d \ln \gamma_{\mathrm{Ca}} m_{\mathrm{Ca}}}\right)_{\mathrm{Ca}}+\frac{2}{3}\left[\left(\frac{d \bar{\phi}}{d \ln \gamma_{\mathrm{Ca}} m_{\mathrm{Ca}}}\right)_{\mathrm{sil}}\right.\right. \\
& \left.\left.+2\left(\frac{d \bar{\phi}}{d \ln \gamma_{\mathrm{Ca}} m_{\mathrm{Ca}}}\right)_{\mathrm{OH}}\right]\right), \quad[11]
\end{aligned}
$$

based on the consideration that there is against one $\mathrm{Ca}^{2+}$ site an area of approximately double size available for occupation by either one $-\mathrm{SiO}_{3}{ }^{2-}-$ group or by two $\mathrm{OH}^{-}$ ions.

For xonotlites I and II, $\left(d \bar{\phi} / d \ln \gamma_{\mathrm{Ca}} m_{\mathrm{Ca}}\right)_{\text {overall }}$ 
TABLE I

Data on $d \bar{\phi} / d \ln \gamma_{\mathrm{Ca}} m_{\mathrm{Ca}}$ for $w=0$ at $\gamma_{\mathrm{Ca}} m_{\mathrm{Ca}}=0.001 M$, and Minimum Equivalent Distances between the Electrokinetic Slipping and Chemisorption Planes

\begin{tabular}{|c|c|c|c|c|c|c|}
\hline Solid & $\begin{array}{c}{[\mathrm{NaOH}]} \\
(M)\end{array}$ & $\frac{d \zeta}{d \ln \gamma_{\mathrm{Ca}_{\mathrm{a}} m_{\mathrm{Ca}}}}$ & $\begin{array}{c}\left(\frac{d \bar{\phi}}{d \ln \gamma_{\mathrm{Ca}} m_{\mathrm{Ca}}}\right)_{\mathrm{Ca}} \\
(\mathrm{mV})\end{array}$ & $\left(\frac{d \bar{\phi}}{d \ln \gamma_{\mathrm{Ca}_{\mathrm{a}} m_{\mathrm{Ca}}}}\right)_{\text {orerall }}$ & $\begin{array}{l}\Delta X_{\mathrm{n}}{ }^{a} \\
(\mathrm{~nm})\end{array}$ & $\begin{array}{l}\Delta X_{\mathbf{b}}{ }^{a} \\
(\mathrm{~nm})\end{array}$ \\
\hline Xonotlite I & 0.01 & 10.7 & $-8 \pm 2$ & 17 & 1.1 & 1.4 \\
\hline Xonotlite II & $\begin{array}{l}0.01 \\
0.002\end{array}$ & $\begin{array}{r}11.5 \\
7.0\end{array}$ & $\begin{aligned}-7 & \pm 1 \\
+7.3 & \pm 0.5\end{aligned}$ & $\begin{array}{c}22.5 \\
9\end{array}$ & 1.7 & $\begin{array}{l}2.4 \\
1.2\end{array}$ \\
\hline Xonotlite III & $\begin{array}{l}0.01 \\
0.002\end{array}$ & $\begin{array}{r}10.1 \\
7.6\end{array}$ & $\begin{array}{l}+4.1 \pm 0.5 \\
+7.4 \pm 0.5\end{array}$ & $\begin{array}{l}10 \\
10\end{array}$ & $\begin{array}{l}0 \\
1.4\end{array}$ & $\begin{array}{l}0 \\
1.7\end{array}$ \\
\hline Wollastonite I & 0.01 & 11.3 & $+6.1 \pm 0.5$ & 10 & - & - \\
\hline Wollastonite II & $\begin{array}{l}0.01 \\
0.002\end{array}$ & $\begin{array}{r}11.0 \\
8.8\end{array}$ & $\begin{aligned}+8.7 & \pm 0.5 \\
+10 & \pm 1\end{aligned}$ & $\begin{array}{l}9 \\
8\end{array}$ & - & - \\
\hline Wollastonite III & $\begin{array}{l}0.01 \\
0.002\end{array}$ & $\begin{array}{l}14.3 \\
10.4\end{array}$ & $\begin{array}{l}-2.8 \pm 0.5 \\
+8.3 \pm 0.5\end{array}$ & $\begin{array}{r}10 \\
9\end{array}$ & - & - \\
\hline
\end{tabular}

${ }^{a} \Delta X_{\mathrm{a}}=$ minimum equivalent distance between the electrokinetic slipping and chemisorption planes, if the stagnant water layer does contain a space charge. $\Delta X_{\mathrm{b}}=$ the same, if the stagnant water layer does not contain a space charge.

thus calculated is found to be $>d \zeta /$ $d \ln \gamma_{\mathrm{Ca}} m_{\mathrm{Ca}}$ for all values of $w$ (see Fig. 1 and Table I). For $w=0$, the difference between $\left(d \bar{\phi} / d \text { ln } \gamma_{\mathrm{Ca}} m_{\mathrm{Ca}}\right)_{\text {overall }}$ and $>d y^{\prime}$ $d \ln \gamma_{\mathrm{Ca}} m_{\mathrm{Ca}}$ is larger at higher than at lower $\mathrm{NaOH}$ concentrations; this is expected if the distance between the electrokinetic slipping and chemisorption planes is approximately the same for those cases. In these cases, we can calculate, e.g., for $w=0$, the equivalent distance between the electrokinetic slipping and chemisorption planes (i.e., the distance if $\epsilon_{\mathrm{r}}$, the relative dielectric constant, $=78.3$ between these planes) from either of two models: (a) The space behind the electrokinetic slipping plane is accessible to ions; thus there is a space charge in this region. (b) The solvent behind the electrokinetic slipping plane has an ice-like structure and is therefore not accessible to ions; thus there is no special charge accumulation at the electrokinetic slipping plane. $d \phi / d x$ then retains its value at the electrokinetic slipping plane, up to the chemisorption plane.

The distances calculated are mentioned in Table I. They may be underestimated because any disorder at the surface (as dis- tinct from surface roughness) will lead to larger distances because of larger differences between $\left(d \bar{\phi} / d \ln \gamma_{\mathrm{Ca}} m_{\mathrm{Ca}}\right)_{\text {overall }}$ and $d \zeta / d \ln \gamma_{\mathrm{Ca}} m_{\mathrm{Ca}}$ (see Fig. 1), but they may also be too large because any lowering of $\epsilon_{\mathrm{r}}$ behind the electrokinetic slipping plane will lead to smaller distances. Thus, if $\epsilon_{\mathrm{r}}$ varies linearly with distance between 78.3 at the electrokinetic slipping plane and 6 at the chemisorption plane, the distance calculated for an ice-like structure of the solvent in this region, for xonotlite $\mathrm{II}$ in $0.01 \mathrm{M}$ $\mathrm{NaOH}$ solution, would become 8.6 $\AA$.

For other solids investigated, $(d \bar{\phi} / d \ln$ $\left.\gamma_{\mathrm{Ca}} m_{\mathrm{Ca}}\right)_{0 \text { verall }}$ for $w=0$ is found to $\leqslant d \zeta /$ $d \ln \gamma_{\mathrm{Ca}} m_{\mathrm{Ca}}$. However, there are arguments for assuming considerable surface disorder in those cases: (a) Samples containing considerable amounts of $\mathrm{Na}^{+}$are enriched in their surface layers toward this ion (about $50 \%$ of it is extracted from the solid after $2.5 \mathrm{hr}$ of contact with aqueous solutions) (7). (b) The wollastonite samples were prepared by thermal decomposition of xonotlite. During this conversion a disordered stage is passed (11), and after conversion some disorder in the stacking of the $\left[-\mathrm{SiO}_{3}{ }^{2-}-\right]_{\infty}$ chains in the wollastonite 
structure is evidenced by diffuse odd layer $\mathrm{X}$-ray reflections (6). Then significant disorder is likely to persist near the phase boundary.

For those solids where an ordered surface may exist (xonotlites I and II), the electrokinetic slipping and chemisorption planes are not identical. The distances between them, however, are much smaller than that corresponding with a stagnant layer hundreds of molecules thick, and agree better with an identity of outer Helmholtz and electrokinetic slipping planes (2), although they appear to be rather large when compared with other estimates of the Stern layer thickness [see, e.g., Ref. (12)]. This discrepancy may be partly due to the abstractions implicit in the model employed, electrokinetic slipping and chemisorption planes being thought of as mathematical planes. Thus, any surface roughness will lead to larger values between these planes.

The fact that significant differences in adsorption characteristics between the solids are found, which can be related to differences in surface structure, excludes the formation of a hydrated surface gel layer under the conditions of our experiments. For, because of the equal $\mathrm{Ca} / \mathrm{Si}$ ratios and the close structural relations between wollastonite and xonotlite, such a layer, if formed, is expected to be identical for these two solids.

The present discussion accentuates the necessity of taking into account surface disorder and local deviations from the average potential near a solid/liquid phase boundary, when discussing chemisorption. Although this is likely to be especially important when the solid phase is an isolator, the effect should not a priori be excluded for other interfaces, such as the AgJ/electrolyte solution interface.

\section{REFERENCES}

1. Drost-Hansen, W., J. Colloid Interface Sci. 58, 251 (1977).

2. Lyklema, J., J. Colloid Interface Sci. 58, 242 (1977).

3. Aveyard, R., and Haydon, D. A., "An Introduction to the Principles of Surface Chemistry," p. 57. Cambridge University Press, Cambridge, 1973.

4. Siskens, C. A. M., Stein, H. N., and Stevels, J. M., J. Colloid Interface Sci. 52, 251 (1975).

5. James, R. O., and Healy, T. W., J. Colloid Interface Sci. 40, 53 (1972).

6. Dent, L. S., and Taylor, H. F. W., Acta Crystallogr. 9, 1002 (1956).

7. van Diemen, A. J. G., and Stein, H. N., Sci. Ceramics 9, 264 (1977).

8. Overbeek, J. Th. G., in "Colloid Science I" (H. R. Kruyt, Ed.), p. 129, formula (44); p. 130, formula (47). Elsevier, Amsterdam, 1952.

9. Hopkins, H. P., and Wulff, C. A., J. Phys. Chem. 69, 6 (1965).

10. Davies, C. A., J. Chem. Soc. 2093 (1938).

11. Heller, L., Proceedings, 3rd International Symposium on the Chemistry of Cement, London 1952 , p. 239.

12. Levine, S., and Bell, G. M., Discuss. Faraday Soc. 42, 69 (1966). 